\title{
The Quest for "Siwilai": A Geographical Discourse of Civilizational Thinking in the Late Nineteenth and Early Twentieth-Century Siam
}

\author{
THONGCHAI WINICHAKUL
}

$\mathrm{O}$

27 DECEMBER 1932, PRINCE BHIDAYALONGKORN, the President of the Royal Institute of Siam, delivered a special lecture titled "What are the conditions called "siwilai?" [Phawa yangrai no thi riakwa khwam siwilai]. Transliterated from the English word civilized, the term was widely used in public without elaboration. Bhidayalongkorn reported that there was a debate whether Siam was or was not yet siwilai, often referring to England, China, Haiti, Tibet, and many other countries, but it was not clear what made them siwilai or not siwilai. He went on debunking the general understanding that wealth, power, territory, monogamy, gender equity, cleanliness, dress, etiquette, or mechanization constituted the notion of siwilai. The meaning was slippery, no matter how anybody tried to claim or use it politically (Bhidayalongkorn 1970).

The lecture was given only six months after the revolution that ended the absolute monarchy, while the tension between monarchists and revolutionaries remained high. It was unmistakably a polemic against the revolutionaries and their supporters, mostly urban intellectuals (writers, journalists, and bureaucrats) who saw absolute monarchism as a major hindrance to the country's advancement and becoming siwilai. That the Siamese elite and intellectuals of all camps had desired to become siwilai since the mid-nineteenth century was not a surprise, as will be explained below. Not unlike the eclectic ideas of what constituted civilization that evolved in Europe over

Thongchai Winichakul is Associate Professor, Department of History, University of Wisconsin-Madison. The larger project of which this article is a part was supported by the Social Science Research Council, Advanced Area Research Grant in 1992/93, the Guggenheim Fellowship in 1994/95, and supplementary grants from the American Philosophical Society during those years. The graduate School of University of Wisconsin-Madison has supported it through various grants between 1992 and 1995. I appreciate comments from colleagues who read earlier drafts or listened to presentations of various forms of this article, especially Craig Reynolds, Lionel Jensen, Pattaratorn Jirapravatti, Kasian Tejapira, Paritta C. Ko-anantakul, and the working group on Geography at Work in Asian History, who met in June 1999 with support from University of Colorado-Boulder.

The Journal of Asian Studies 59, no. 3 (August 2000):528-549.

(C) 2000 by the Association for Asian Studies, Inc. 
many centuries (Elias 1978), ideas on how to make Siam siwilai ranged from etiquette to material progress, including new roads, electricity, new bureaucracy, courts and judicial system, law codes, dress codes, and white teeth. The list could be much longer. But unlike the European experience, the Siamese quest for siwilai was a transcultural process in which ideas and practices from Europe, via colonialism, had been transferred, localized, and hybridized in the Siamese setting.

Given its slippery meanings, how was the idea of siwilai conceptualized in Siam at that time? How did the Siamese assert Siam as a siwilai country? This article argues that the quest for siwilai was not simply a reaction to the colonial threat. Rather, it was an attempt originated by various groups among the elite, later including urban intellectuals, to attain and confirm the relative superiority of Siam; as the traditional imperial power in the region, Siam was anxious about its position among modern nations. By the mid-nineteenth century, however, superiority had to be obtained in a new world order in which Europe was at its zenith and whose ethos was "civilization." Although not formally colonized, Siam was under the global influence of European colonialism. But the civilizing process was never simply an imposition or imitation. At the "contact zone" of transculturation, a notion borrowed from Mary Louise Pratt (1992), the Siamese intellectuals and elite played active roles in the appropriation and localization of the ideas and practices of siwilai. The important point is that there was no definitively essential quality of siwilai. The concept of siwilai was always relational, and the relative position of Siam on the civilization scale was conceivable by spatial discourses.

Around the turn of the century, between the 1880 s and the 1920 s, travels within Siam and to Europe, ethnographic writings, domestic exhibitions, and World's Fairs mediated the discursive evaluation of Siam's siwilai by producing a conceptual scheme of different space of siwilai, from forest, village, city, to Europe, each of which represented varying levels or degrees of siwilai. We may say that the spatial discourse of siwilai was a comparative geography of civilization, given that "geography" can mean not only the arrangement of actual space and the knowledge of it, but also the knowledge and discourses whose effects subsequently constitute spatial practices.

\section{Siwilai, the Term: Meanings, Substitutes, and Its Politics}

The word siwilai was among the earliest transliterated words from English, dating from the middle of the nineteenth century, and one of only a few which survive in their transliterated form. It is not clear how widespread the use of the term was in those early decades, but by the final decades of the century the term and whatever it signified was used and discussed widely by writers and intellectuals both inside and outside the court. There were several attempts to substitute a Sanskritized Thai or more familiar Thai terms with approximate meanings for the English transliteration. These attempts have had varying success. Drawing from Sanskrit, for example, the term ariya or araya was adopted for "civilized," and "arayatham" (araya + dharma) for "civilization," from the time the English terms were introduced. The latter remains in current usage, while its transliterated form, "siwilaisechan," faded away long ago. The word araya, on the other hand, never became popular, although it survives as a stylized or unusually formal word, such as might be found in poetry.

The transliterated siwilai, meanwhile, remains in use, having become a common word that can be used as an adjective, a noun, or a verb, interchangeably, both in 
writing and speaking. ${ }^{1}$ These philological innovations were evidence of the efforts to localize the term and concept for local comprehension and consumption. The success of the transliterated term indicates that there are needs (consumption, users) in the Thai context for such a concept, but that there is no adequate substitute for it. Nevertheless, the transliterated form is a trace that the concept has an alien origin.

Siwilai was a subject with which King Mongkut (r. 1851-1868) and probably the elite of his generation were concerned. He had sought explanations about it from his Western friends since before coming to the throne. He even admitted that Siam was half-civilized and half-barbarian (Charnvit 1996, 3-6). Apparently, as diverse politically as they were, all the elite wanted Siam to be siwilai. They also rejected any attempt to couple siwilai with Christianity, remaining firm believers in Buddhism. ${ }^{2}$ Beyond that, their understanding, interpretations, and aspirations for siwilai became increasingly contentious. As in English, siwilai connoted a wide range of meanings. ${ }^{3}$ On the one hand, it referred to refined manners and etiquette. A famous intellectual at the turn of the century commented that the changing norm of Thai men to wear shirts marked the departure of Siam from being barbarian to becoming "siwilai like the Europeans" (Kulap 1995, 81-82). This meaning was later developed into the normative discourse and codes of conduct such as the influential treatise in Thai, Sombat kbong phudee [Qualifications of the gentility]. ${ }^{4}$

On the other hand, as in English, siwilai was loaded with the ideas of "an achieved state of development"or progress. ${ }^{5}$ As a Thai historian observes, "Western things and ways of conduct" (Charnvit 1996, 6) were considered siwilai. But, in fact, the localization process was never simple or smooth. Given different interpretations, especially in this second sense of the term, siwilai became more politicized in Thai cultural history until it became an arena of political struggle, as suggested in the lecture cited at the beginning of this paper. Critics at the time were mostly urban literati (intelligentsia, bureaucrats), whose concepts of siwilai were increasingly influenced by nationalism and less by royalism. The louder the calls for changes in political and public affairs in the name of siwilai, the stronger and more serious were the rebuttal and counter arguments based on different views of siwilai.

'Another smart invention was a compound word "sriwilai." Sri is a Sanskrit term meaning blessing, prosperity, brightness, beauty; wilai means beauty. Literally sri + wilai $=$ bright + beauty. Phonetically, it is almost identical to its English original. But it was never adopted into normal language, appearing infrequently only in stylish prose, poetry (Mahintharasakthamrong 1988, 83, 99), and proper names such as Princess Sriwilailak, a daughter of King Chulalongkorn, and a famous Thai actor of the 1970s, Krung Sriwilai.

${ }^{2}$ The best example of this is Thiphakorawong 1971, originally written in 1867 . See Reynolds 1976 and Thongchai $1994,40-42$ for discussions on this book.

${ }^{3}$ See Elias 1978 for the range of meanings of the word in the German, French, and English contexts.

${ }^{4}$ This influential treatise was written by Chaophraya Phrasadet Surentharathibodi in 1900. The text is, in fact, very short: a list of 182 items of what to do and what not to do without elaborations. In each edition, however, elaborations and additional explanations are added as appendices. The appendices, which are much longer than the original text itself, are crucial. The good behaviors include such areas of "Westernized" conduct as taking off hats, pipe smoking, and table manners. But the behaviors that are considered Thai and Buddhist are also covered.

'The quotation is from Raymond Williams 1983,58 , in which he discusses the sense of the term civilization in English from the eighteenth century. Williams notes the "spirit of the Enlightenment," the secular and progressive development, and the condition of "modernity." Yet he recognizes that the meaning is inherently relative. 
It was the second sense of siwilai that found another term with approximate meaning, "charoen." Etymologically a Khmer word, it can be found in the fourteenth century and probably earlier. ${ }^{6}$ In the older sense, it means cultivating, growing, increasing, building up or expanding until complete in a positive sense. It is applied mostly to nonmaterial matters, such as cultivating merit and Buddhist awakening, making (someone) happier, growing up, increasing maturity, and so on. This older meaning of charoen gave way in the nineteenth century to connoting secular or worldly development, material progress, and technological advance, until it became an alternative to the alien word siwilai in this larter sense. This new meaning has since become part of normal vocabulary, and charoen is used interchangeably with siwilai.? A geographical textbook in Thai from that time clarified the term:

The word siwilai... is similar to a Thai word, 'charoen'.... A human race considered siwilai is the one who is mature, behaving properly according to the norms, ... intending to contribute to make their country charoen... . The country which is more siwilai is the one whose people are mostly siwilai.... When Thai people are more siwilai, the country becomes increasing charoen siwilai too.

(Tharaphakphathi 1904: quoted from many sentences in pp. 157-62)

Siwilai and the new notion of charoen clearly indicated the sense of transformation into the new age, or modernity, as opposed to the traditional, the ancient, or the bygone era. This sense of secular development and material progress is more obvious in another term, "than samai," which also emerged in the late nineteenth century and became influential in the 1960s modernization. Literally, it means keeping up with the age or with the times. Indeed, these terms point to the forward and backward directions of time, rather than the recurrence in the predetermined and static cosmic time as in the Hindu-Buddhist sense of the past. As I hope to elaborate elsewhere, siwilai and the new meaning of charoen were part of the emerging temporal consciousness in which history, progress, and nostalgia were conceivable. For the purposes of this article, it was clear that Siam had a mission to keep up with the times. ${ }^{9}$

\section{Siam in the "New World Order" of the Nineteenth Century}

Colonialism was not only a political and economic project, but also a cultural and intellectual one that had induced drastic changes in local cultures across the globe.

"In the old usage, the more common form of the word is "chamroen." See, for example, Phya Lithai 1983, 2, 58, 67; Phra Thampricha 1992, 16-17, 431. In modern Thai usage, the word can be made into a noun by adding the prefix "kbwam" [-ness].

${ }^{7} \mathrm{~A}$ recent anthropological fieldwork in a remote Thai province notes that the emphasis of charoen is on material conditions such as paved roads, electricity, machines, and modern buildings (Delcore 2000, 60-61, 288-89). I would concur with this observation.

'In the Thai language, the fact that the two words are put together as a doublet in the last sentence indicates their synonymity.

"An interesting comparison with similar processes of localization of the "civilization" concept can be found in Fukuzawa (1973), For Fukuzawa, a well known intellectual of the Meiji, Japan, the "West" was also a goal, but Christianity was likewise decoupled from the road to civilization. What the "West" meant for him, however, was more the virtue of knowledge and much less the material modernization. 
Siam in the nineteenth century faced what Pratt calls a shift in "planetary consciousness," in which Europe "differentiated conceptions of itself in relation to something it became possible to call 'the rest of the world' " as a result of colonial encounters (Pratt 1992, 9 and 5). The process of colonial transculturation was hardly a simple imposition, diffusion, or imitation of knowledge and practices. It always involved localization by local agencies to suit their settings and, more often than not, serve their interests. Pratt again has emphasized the role of the "Contact Zone" of transculturation in which she means:

the space of colonial encounters, the space in which peoples geographically and historically separated come into contact with each other and establish ongoing relations, usually involving conditions of coercion, radical inequality, and intractable conflict. ... (The) term 'contact' ... foreground(s) the interactive, improvisational dimensions of colonial encounters so easily ignored or suppressed by diffusionist accounts of conquest and domination.... It treats the relations among colonizers and colonized ... in terms of copresence, interaction, interlocking understandings and practices, often within radically asymmetrical relations of power.

(Pratt 1992, 6-7)

Siam in the nineteenth century was at a critical period under colonial threat. Because of that and the fact that Siam finally escaped a conquest, the conventional historiography of Thailand always suggests that the "modernization" since the midnineteenth century was a necessary measure to save the country by satisfying the Europeans or minimizing the preconditions of colonization. The brilliant Thai monarchs saved the days. ${ }^{10}$ I would argue that the active role of the Siamese rulers in the transformation was unquestionable. But the attention to threat and anxiety has obscured another motivation for change that was not less true, namely, desire, as if the Siamese elite were forced to act for survival and the quest for siwilai were solely tactical. While they were anxious, the Siamese elite were not hostile to Westerners. Many generations of Thai elite since the middle of the century were very fond of the farang (Westerners), and their craving for things Western was well known. ${ }^{11}$ They were especially receptive to the British and adopted a pro-British policy until they felt betrayed during the Franco-Siamese crisis in 1893 (Chandran 1970; Thongchai 1994, 108-9). The Europeans became a real threat to Siam late in the century. The desire for charoen was genuine, not only compelled by colonialism, and it was common among the aristocrats and urban intellectuals inside and outside the court alike. ${ }^{12}$ This is understandable if we take into account their changing views of the world.

${ }^{10}$ Wyatt $1983,180-212$, is an example of this historiography. To be fair, he lays out the complexity of the situation that the Thai monarchs faced, from factionalism within the courts to generational conflicts, to security issues, both internal and external. But the foreground of colonial demands and threats, and the emphasis on the ability of the monarchs to ensure the survival of an independent Siam, are over-determining. Despite that, Wyatt's account is pale in comparison to the conventional historiography in Thai in which colonial threats were the prime explanation for almost every change at that time. The stronger the presence of the mighty enemy, the more heroic the monarchs were. They were anti-colonial heroes without being colonized.

${ }^{11}$ There are numerous instances of this. See, for example, Vella 1957 and Bradley 1981. The second king during the reign of King Chulalongkorn was given the nickname "George Washington" by his "Americophile" father, according to Wyatt $(1983,191)$. Even the generation of princes and nobles that became known in the 1870s as the "old guard" or the "ancients" (Wyatt 1983, 192) embraced the new knowledge and technology from the West.

${ }^{12}$ One of the best examples is Chai-anan and Kattiya 1989, 31-135, a collection of political 
In the older world order, the legitimation of power of an overlord was claimed by establishing his genealogy or association with the supreme sources of power. The claims were comprehensible in two ways. The first one was the religious ideology in which the overlord claimed his supremacy owing to his ability to access the superior sources of cosmic power, be they the Hindu gods, the Buddhist power (bun and barami), or all of them. He was the center of a microcosm located in a capital city, but whose genealogy of power could be traced back to origins in Jambudipa, the mythological realm which was identified with modern India (see Tambiah 1976, 4151, 102-11).

The second comprehension of the world order was the complex system of tribute payment and mutual recognition. Exchanges of gifts and tributes, conferring of honors, and offerings of women among the higher and lower kings, and among comparable ones as well, signified the relative status of the givers and the recipients. Despite the ideological conventions of claiming to be at the zenith of the world, all kings in the region realized their positions as one among many kings of various positions in the hierarchies. A Siamese king, for example, exercised his superior power over tributary kings, while being fully aware of his Burmese counterpart, who also exercised power, probably over the same tributaries. Apparently, moreover, the regional overlords, such as those in Siam and Burma, realized and sometimes acknowledged the claims by Chinese emperors as being the superior power above all regional kings. Yet, China was distant and, since the thirteenth century, was never directly involved in the relations among regional kings. In short, Siam knew its position as a, not the, supreme overlord in the region. But India and China remained the axis mundi of the world, ideologically rather than in actual political relations.

By the mid-nineteenth century, both India and China were defeated by the Europeans. Soon, the "enlightened" generations of the Siamese elite, such as the one led by King Mongkut, denounced the traditional view of the world. In a proclamation against sending a tribute mission to China, Mongkut ridiculed the Chinese selfproclamation as nonsense. As for the past kings of Siam, he censured them strongly for stupidity, "without intelligence to learn more about other countries, . . . knowing very narrowly only about China," thereby giving too much credit and unnecessary homage to China (Mongkut 1973, 41-58, quotation from pp. 43 and 56). ${ }^{13}$ The last mission to China was in the early 1850s (Cushman 1993, 138). Likewise, in a correspondence to a senior Burmese monk, he lectured him that the Hindu-Buddhist world view that honored India (a.k.a. Jambudipa) as a holy place, as the beginning of sacred lineages, was an incredibly archaic belief (Phraratchaputcha 2:145-67). Any people who held such beliefs were ignorant of the "true facts about the earth," i.e., geography (Bowring 1969, 2:144).

I would argue, following Pratt, that this was a new consciousness of the world in which Siam had to reconceptualize itself in relation to the rest of the world, including the new supreme sources of power. It was no longer at the zenith of a regional microcosm of the cosmos. Nor was it of the world in which the Chinese emperor sat on the top, or of an extended sacred land from the Hindu-Buddhist Jambudipa. In the new world order, Europe emerged as the new axis mundi. And its ethos was no

documents from 1885 to 1903 , which includes the petition by a group of young officers, a few essays by a famous intellectual outside the court, and comments by King Chulalongkorn in response to them. Apparently, all of them wanted the country to be charoen or siwilai, but disagreed on what to do.

${ }^{13}$ The proclamation aimed at criticizing the previous king, Rama III, who was a Chinese enthusiast and had been in charge of trade with China. 
longer cosmic like heavens or gods. It was civilization. In the ancien polity, the independence of a country may not have value in itself. Rather, it is an evidence of the waxing or waning superiority of an overlord. For a country to survive, it meant the ruler could maintain or enhance his superiority. Siam could no longer confirm its relative superiority and its meaningful existence by claiming the lineages to the traditional cosmic origins. In order to survive, not from colonialism but from indignity and inferior existence, and to remain majestic, Siam needed a confirmation according to the new ethos of civilization that it measured up to other leading countries. The desire and anxiety to keep up with the world, not an escape from being colonized, was significant in itself. The question remains how Siam evaluated its level of siwilai, or the lack thereof, given contesting interpretations what it should mean. As we shall see, the level of Siam's siwilai was comprehensible by a geographical discourse that placed Siam in relation to "the Others" from both within Siam and without to "Europe."

\section{The Others Within ${ }^{14}$}

In many ways, what the Siamese elite did was similar to the colonial construction of the Others: that is, they traveled, wrote ethnography, and organized exhibitions and museums as means to construct the otherness. Unlike the colonial otherness, however, the Others of the Siamese elite included their own subjects, hence the Others within.

In Siam, until the nineteenth century, there was no travel literature that informed us of any travels for pleasure or secular knowledge. Apart from the administrative reports of journeys, a poetic genre particularly for travel, Nirat, typically was a male's lamentation over travel, for it meant the separation from his loved ones and from the comfort of home. It became a poetic convention for a love-separation melancholy with the chronology of travel used merely as background or setting. Sometimes the journey was imaginary for poetic expression (Manas 1972). Except for pilgrimages, travels were mostly for trade, business, administrative, or military purposes and were probably not much of an enjoyment. A shift took place in the nineteenth century as a Nirat gradually became a mundane travelogue, or an account of a military expedition, or of an eye-opening trip to exciting places, or a tale of an entertaining tour. The new kind of Nirat was preoccupied mostly with the chronological accounts and descriptive reports of people and their environments. Instead of sadness, they were full of excitement and satisfaction. This poetic transformation reflected the changing culture of travels in the same period. By the end of the century, a leading intellectual suggested that the two aims of travel were pleasure and knowledge (Damrong 1961, $1-5)$. During the 1880 s to 1920 s, excursions to distant places in the interior of Siam and abroad for curiosity and pleasure became popular among the urban elite and intellectuals. Travelers wrote quite a number of reports, diaries, and stories based on their experience. Many of them were ethnographic records similar to what we might call "field notes."

These writings followed one of the two patterns, according to the categories of people encountered. It appears that travelers wrote what they learned in a certain order and described the peoples they encountered in a certain pattern, although none was ever formally sanctioned. The distinctive patterns they followed in reporting helped

${ }^{14}$ For the extensive version of this section, see Thongchai 2000. 
constitute the discursive differentiation of peoples. These writings were instrumental to the discursive construction of a conceptual scheme of two kinds of the Others, differentiated by two spatial domains.

The first kind of people encountered were the chaopa, literally the jungle people or people of the wilderness. While traveling along the borders of the emerging geobody of Siam, in the mountainous areas between Siam and Burma, and in the highland areas of Laos today (Lan Sang, Phuan, and others at the time), Siamese commanders and administrators wrote ethnographic notes about several peoples they encountered. One of the earliest writings I have found stated clearly that the article "intends to describe the kind of kbondoem" [natives, autochthonous people] but not the Lue or the Shan who are "like the Lao or Thai people like us" (Prachakhadikit 1885, 164). The description mentioned many peoples, including the Karen, the Lua or Lawa, Khamu, Lahu, Hmong, and the Mrabri. In each case, a few sentences are given to describe only distinctive features such as clothes, hairstyles, house, plants, food, and weapons. Considered worthy of mention are unusual or strange features to the readers (in Bangkok). The strangeness of these peoples is even more conspicuous in the better known document originally written in 1889, "Waduai chaopa chat tangtang" [On various jungle races]. Definitely infuenced by colonial anthropology and the racial discourse of the late nineteenth century, the notes on each race contain the observed data orderly itemized into topics such as physical description (eye colors, hair, skin, lips), and living conditions and cultures (styles of housing, dress, language, beliefs, coinage, and birth, funeral, and wedding rituals) (Surasakmontri 1972).

Those peoples were gazed at, dissected, catalogued, recorded, and described as objects. Rarely was there a "story" or the presence of individuals. The people were described collectively as races or tribes. Their distinctive feature is strangeness, that is, the characteristics or customs that deem them incredible and unexpected to the authors and their readers. What strangeness connotes is clarified in the introduction to the 1889 document mentioned above.

The peoples of this kind live in the jungles on the mountains at the frontiers far away from town (banmuang). But they never settle down in any place or having any homeland, preferring wandering in the jungles. Suppose that any country kindly wished to take care and protect these races, they may not be able to absorb the charoen anyway. They might naturally avoid or escape, in order to return to jungles and mountains.

(Surasakmontri 1972, 242)

In short, they were uncivilizable peoples, no matter how much we might try. The term $p a$ and its synonym in Thai, thuan, or the doublet, patbuan, mean both the wilderness and uncultured or barbaric (behaviors, people) at the same time. Even before the word siwilai became popular, pa was an antonym to explain the idea of siwilai. In 1851, Mongkut stipulated that anybody who had an audience with him must wear a shirt "like in other major countries," but unlike the "chaopa, the inferior human beings" (Thiphakorawong 1961, 6). As mentioned earlier, this change was praised as a departure from being like the pa people to becoming siwilai like the Europeans (Kulap 1995, 82). ${ }^{\text {15 }}$

${ }^{15}$ The current term for these peoples has changed to chaokbao, literally mountain people. The discourse of chaokbao is similar to the one of chaopa, i.e., strange and uncivilized tribes. But the term chaokbao carries more prejudice in that people so described are associated with drugs and security problems. 
The second type of Others within Siam were the chaobannok or rural villagers. The narratives of travels to the rural areas of Siam are not short notes categorized into topics about the uncivilizable races and their strange customs. The countryside was not strange to the city travelers. Indeed, they were so familiar with rural people that the narratives are full of details, rather tedious accounts, of daily events, such as the endless number of receptions hosted by local authorities (since many travelers were lords), temple visits, and tours of local exotica and scenic places. The presence of the crowds of local people, be they Thai, Mon, Lao, Khmer, or others, is noted in the narratives as are stories of some individuals. The elite travelers recognized the multiethnic subjects and their different cultures quite well. Ethnic differences were not significant for they were all "chaobannok," the rural folk who toiled the lands and produced. The descriptions are full of records about landscape, natural features, farms and crops, flora and fauna, and about the livelihood of people, their customs, communal activities, occupations, trades, crafts, and local products. These people and environments are, in today's language, human and natural resources. They had economic value. They were the exploitable people and space, hence the narratives of the crowd and resources.

One of the major characteristics of chaobannok was the stereotype of the uneducated and backward folk. There were quite a few stories of magic, superstitions, intriguing talent or unusual persons. One of the best known collections of stories of the chaobannok is Nitban borankbadi by Prince Damrong Rajanuphap, the architect of the modern Thai state who traveled extensively to the interior of Siam during the integration of former tributaries. He was also one of the most influential modern Thai intellectuals and is recognized as the Father of Thai History. Literally, the title of the book means fables or stories from/of the past. Actually, all of them were accounts of rural people Damrong encountered during his travels to the interior of Siam in the early decades of the twentieth century. They were Damrong's contemporaries who happened to live in the backward space, in the domain of simplicity, superstition, ignorance and uneducatedness, that is, less siwilai, which was the past of siwilai. Those people were in the past of the city traveler. To borrow Fabian's words, despite coevalness, the traveler found chaobannok the Other in time (Fabian 1983).

Both chaopa and chaobannok were two categories of the Others of the more siwilai elite. The chaopa were the uncivilizable; the chaobannok were the loyal, backward subjects. The gazers were the educated elite in the city, the people and space of siwilai and charoen. It should be noted that there were peoples who were described in one way or the other between the two categories. The prime example was the Lao (people and regions). The Lao as a people have been treated as inferior to Thais, and Laos as a country has often been looked down by Thais as the little brother of Siam (Thaweesilp 1988). Writings about the Lao during the period we are discussing mostly described them in details like chaobannok. At times they were mentioned as non-chaopa, similar to Thais. Yet, Lao people were also mentioned as chaopa and some accounts dissected Lao customs and described them topically similar, to the description of chaopa (see Lattbi thamniam tangtang, parts 1 and 18). ${ }^{16}$ For the Thai elite, the Lao were somewhere between the two kinds of Others.

${ }^{16}$ Originally published in the journal Wachirayanwiset in 1896 as three separate essays, part 1 of Latthi thamniam tangtang was put together in the first printing of the book in 1918 with the title "Latthi thamniam lao" [Customs of the Lao people]. It was changed in subsequent printings as "Latthi thamniam ratsadon phak isan" [Customs of people in the northeastern region], with an introduction stating that those people in the northeast are, in fact, Thais, and that Lao people are also a branch of Thai people. The word Lao everywhere in the text was changed accordingly. Yet the rest of the essays remain intact. 
Before the modern notion of a sovereign power over the entire territory, pa was the domain beyond normal social and political power as opposed to the ones under it-ban (village) or muang (town, country) or the doublet banmuang. A polity and power in the Hindu-Buddhist tradition was not merely secular but indeed religious as well. An area under or outside the "umbrella of merit" implied the cultural or spiritual quality too (Stott $1991,145-46$ ). $\mathrm{Pa}$ was inhabited by wild animals and spirits, who could be benevolent or malevolent, and some very powerful. Those spirits were outside and inferior to the power of dharma. Buddhist monks often take pilgrimages to jungles to improve and test their dharma power, as it is often said, by subduing the wild animals and spirits, or more precisely, to overcome their own fears of those dangers in the pa (Kamala 1997, 79-96). The spiritual quality of individuals and places varied by their proximity to the sources of dharma or other cosmic power, including the kingship. Even though it might have powerful spirits residing in it, as a domain pa was inferior to a rural village, a town, or a city. Spiritually speaking, the city was the enlightened space, the most charoen, as opposed to the jungles of the heathens. A rural village was remote from the spiritual center and adjacent to the $p a$.

It is very likely that this spiritual hierarchy of space that preexisted the idea of siwilai had facilitated the spatialized classification of siwilai in Thai thinking. In other words, the compatibility between the two epistemic concepts provided the possibility for the ideas of comparative siwilai space to be appropriated into local consciousness. Whereas the traditional categories of spiritual geography informed the position of Siam in the religious world view, the geography of siwilai informed the modernizing Siam of its position in the new world order. Culturally speaking, Siam was not an undifferentiated country. It remained hierarchical, this time by different levels of siwilai. Forest, rural areas, and city are differentiated spaces of civilization. The elite considered themselves and the city as the representation of Siam. The chaopa and chaobannok were the Others Within.

\section{"Europe" as a Threat and "Europe" as a Trope of Siwilai}

As argued earlier, the quest for siwilai was not as much a necessity or a genius strategy for independence and survival as a desire to maintain relative superiority. As early as the 1830s, "Europe" was as much desirable as a cause for concern to Siam. The notion that the sun never set on the British Empire was more fascinating than intimidating. Throughout the history of Siam, the supreme powers in the world were the cause for concern as much as for excitement and inspiration. Jambudipa (India) and China before colonialism, and the United States after World War II, occupied similar positions in the Thai mentality. "Europe" at the time was not much different.

From the 1880 s, stories and information about Europe, its geography, histories, peoples, and miscellanies poured onto the pages of publications in Siam. Stories from newspapers and magazines in English, such as the ones from Singapore, were translated or retold. Quite a few of them, then, described "Europe" at heard second-hand, thirdhand, or merely as hearsay. A few magazines, for instance, Thalokwitthaya, were dedicated almost entirely to stories about Europe. "17 "Europe" became a signifier in

${ }^{17}$ Thalokwitthaya was published between 1900 and 1905; see at the National Library in Bangkok. Microfilm \# 30/108 and 30/111. 
the discourse on siwilai, referring to a distant land that was the imagined model for progress and desirable changes.

As a model, many desirable conditions were attributed to "Europe," no matter whether they were really true in Europe. A striking example was the idea that Europe was a model for harmony. At least twice (1875 and 1907), two prominent intellectuals argued that Europe was so successful for siwilai and charoen because its people and government were harmonious and unified (Thianwan in Chai-anan and Kattiya 1989, 123 , and Mahintharasakthamrong 1988, 65-67). In his rebuttal to this opinion, King Chulalongkorn rightly pointed out that the Europeans were hardly so (Chai-anan and Kattiya 1989, 127). Regardless of truth, "Europe" appeared to be a generic trope for siwilai, modernity, and progress.

Not everything European was favorable, however, and neither were living traditions swept away. Buddhism and polygamy, for example, were empathetically reaffirmed and excused, respectively, in the major text that endorsed the modern scientific knowledge (Thiphakorawong 1971). Chulalongkorn's rebuttal above was a criticism of those who called for political reform following the European model, including a parliament and political party. For everyday life, while shirts were on, many new practices were merely superficial to make themselves look nonbarbaric. A good example was the effort by everybody during Chulalongkorn's first trip to Europe in 1897 to quit chewing betel nuts and remove the black stains built up on their teeth (Chulalongkorn 1962, 2-5). Black teeth had been a mark of beauty in Siam until siwilai needed them white. The selective appropriation of "Europe" by local agencies was common, and their disagreements often became highly political. This happened not only in Siam, and probably continues to occur.

King Chulalongkorn himself was a great fan of Europe. He had expressed his wish to go to Europe to see "charoen" ever since he assumed the throne in 1868. Due to difficulties in transportation from Siam to Europe at the time, and to the fact that there had never been a Thai king going as far as Europe before, the king was instead sent to Java and Singapore, colonies of the Europeans. There he was excited to see new technology and modern institutions, including prisons and museums. He became even more eager to visit the real Europe itself. Finally, the king fulfilled his wish thirty years later in 1897, four years after the tragic Franco-Siamese crisis.

The significance of the crisis could hardly be exaggerated. Although the meaning of the crisis for Siam, as I have argued elsewhere, may not have been as jeopardizing to Siam's independence as generally thought, nonetheless, the Siamese rulers were undeniably shocked by the defeat in the 1893 crisis (Thongchai 1994, 128-31, Battye 1974, 369-96). Ever since, paranoia about foreign threats to Siamese independence have been part of the Thai mentality, elitist and popular alike. Chulalongkorn's trip has therefore been seen as a major diplomatic success that guaranteed Siam's independence by showing to the European powers that Siam was not a barbaric, but a civilized nation. Despite the popularity of this interpretation among historians of Thailand, especially among the Thais, I doubt if the trip to Europe changed the imperial policies of those major powers regarding Siam. It is even less probable that if they did change, it was due to their changing view of Siam as a civilized country. The Franco-British Declaration of 1896, before the king's trip, in which both France and Britain agreed to leave the Siamese territory as a buffer zone, was by far the more effective guarantee for the independence of Siam (Chandran 1970). As a matter of fact, neither Britain nor France prepared for or paid much attention to the royal visit (Chalong 1997). The only accomplishment diplomatically was the cordial relations established with Nicholas II, the new Russian Tsar, who was pursuing Russian 
imperial policy in the Far East, but who had some influence in Europe during that time. The siwilai Siam shown to the Europeans, besides, was at best the localized European practices and the indigenous customs that had already been transformed. More precisely speaking, they showed the hybrid siwilai.

The journey to Europe, I would argue, was a genuine quest to experience the source of siwilai firsthand. The 1893 defeat by France was so agonizing because it was a danger to the country as much as it was an affront to the royal dignity. It was a blow to the king and his royal associates that they and Siam might not be on a par with other sovereign rulers and their kingdoms. This was indeed the older notion of losing "the supreme royal power" (phraborom dechanuphap), known in our modern language as "sovereignty." The attainment of siwilai, to make sure that the country and the king remained relatively superior, became one of the most urgent tasks. Peleggi (1997) recently showed that the court invested enormously in the arts, Italian and Victorian buildings, royal paraphernalia, and public rituals. Consumption was a means to imitate and catch up with the Europeans. Compared to the ancient rituals that were followed to obtain, or at least have access to, cosmic power, the journeys to Europe plus the imitation and consumption of European culture were the modern methods of obtaining and gaining access to the new cosmic power, i.e., siwilai. The gigantic reception and extravaganza held upon the king's return marked the success not of any diplomatic negotiations but of making the trip to Europe itself. Apparently, the word "charoen" was prominent in every speech.

The accounts of the Siwilai Other or "Europe" contain descriptions of gratifying experiences as opposed to those of exotic primitivity or nostalgic simplicity of the Others within. Every country received the Siamese monarch properly and adequately, including France, which at first did not welcome his visit, but changed its mind, thanks to the Russian Tsar. But not all European countries that he witnessed were uniformly civilized. In Chulalongkorn's own accounts, Switzerland (nature, landscape, and people) was graceful and elegant. Italy was the greatest place for arts and crafts, although a little dirty. Austria-Hungary was too formal and not quite enjoyable. He felt most at home with the Russian Tsar, who received him with great dignity, and was as warm and friendly as if they were brothers. He did not like France, which is understandable, since France might be difficult for any royalty to like, especially only four years after the conflict. England did not pay much attention to the king's visit either, giving as an excuse that the country was too busy with the Golden Jubilee of Queen Victoria. Never did England offer a reception at the expected level. Despite that the king found England full of exciting and fascinating things to do and the royal troupe stayed there longer than anywhere else. On many occasions, they were received and taken care of by British genteel and wealthy people, but not by the British royalty (see Chulalongkorn 1962 and 1983).

It should be noted that even though most Thai travelers at that time had never been to Europe, they were familiar with "Europe" through reading about it. The flux of essays, translations, and stories about Europe gave them ideas, not unlike the king's travelogues. Like most tourists who familiarize themselves before a trip, their experience mostly confirmed what they anticipated. Actual travels and imaginative ones via publications reinforced one another, and it is probably difficult to say whether the experience from actual travels formed their knowledge about Europe, or whether the imagined Europe derived from the texts shaped their experience and comprehension of Europe during their actual trips. In every case, the trope of Europe as the desirable model for siwilai was confirmed. 
The gaze outward at Europe was different from the one upon the Others within. For the latter one, it was the Orientalizing gaze upon the inferior others, not unlike colonial administrators and anthropologists looking down upon the Orientals. The gaze at Europe, on the other hand, was the opposite: a looking up in search of an uplift, a cautious, curious, and humbler look with anxiety and self-protective concern. Europe did not appear as a strange object to dissect into topics or as a crowd of uneducated and entertaining subjects. It was full of individuals, with names and characters, who had the abilities to gaze back and engage in dialogue. Both the Orientalizing and the anxious gazes combined to create a gaze from the contact zone of cultural encounter. It was ultimately a very ambivalent gaze: a self-searching with a sense of humility and uncertainty on the one hand, and arrogance and confidence on the other, with aggressive and defensive attitude at the same time, with both great admiration and distrust toward Europe, and both derision and benevolence to the Others within. The quest for siwilai by the Siamese elite did not operate in a binary conception of the world, the West versus the rest, as in Orientalism or in anticolonial perspective.

\section{The World of Siwilai in Spectacle}

The comparatively spatial discourses of siwilai were visually displayed in exhibitions and museums, both domestically and at the World's Fairs. There was a proliferation of exhibitions and museums in Europe and America in the second half of the nineteenth century. Two prominent themes were repeatedly pronounced at several World's Fairs: the advance of Western civilization and the exoticism of the Others from the rest of the world. World's Fairs became a competitive ritual among the industrial countries to boast their advance of science and technology, industrial developments, and other evidence of progress (Benedict 1983, 6-12). On the other hand, most major World's Fairs, especially those after the one in Paris in 1889, displayed the superiority of the imperial countries and their conquests (Rydell 1984; 1993). The Columbian Exposition at Chicago in 1893 and the 1904 Fair at St. Louis emphasized the displays of these "anthropological" exhibits (Rydell 1984, chs. 2 and 6, esp. 55, 160-63). Different parts of the world were recreated at the fairs with thousands of native peoples reenacting their daily lives in artificial villages. The account of the Cairo Street at the 1893 Fair is well known (Mitchell 1988, ch. 1). Other popular ones included the six villages and over a thousand villagers from the Philippines, which spanned over forty-seven acres at the 1904 Fair (Rydell 1984, 165-78), and the displays of peoples from Java, Laos, Cambodia, Annam, Ainu, Algeria, Tunisia, Somalia, Cameroon and others (Benedict 1994, 59-61 which is the list of the colonized peoples at World's Fairs). These real life displays became famous features of several other fairs. The fairs were a microcosm of the colonial world order. Various levels of civilization were unmistakably on display, on the one hand by science, technology, and industrialization, and on the other by exotica and primitivity which, in the eyes of the colonizers, belonged to the past.

The Siamese elite were quick to catch up with the latest global vogue. They believed that their participation in those major fairs would increase their recognition and elevate their status in the eyes of the world. Yet they appropriated exhibitions, museums and the World's Fairs in the ways they understood them and saw their benefits. Siam participated in the World's Fairs as early as 1867 in Paris and 1876 in 
Philadelphia (Taylor 1991). Participation was carefully selected and a large number of invitations were turned down, nonetheless, because of limited finances. Despite that, it is amazing that Siam rarely missed the major ones. It exhibited at World's Fairs in Paris (1889 and 1900), Chicago (1893), St. Louis (1904), and Turin (1911), even though it was costly and involved a great deal of effort each time. ${ }^{18}$ It appears that Siam did not want to miss being part of the world's gala, even though it was a showcase of world colonialism. It was not clear whether the Siamese government was aware of or cared about the colonial ideology embedded in the fairs. ${ }^{19}$ The Siamese pavilion was usually located among the independent countries from the Far East or among the exotic, the half-civilized, or the inferior civilizations, such as among Haiti and the Caribbean islands at the Chicago Fair. ${ }^{20}$ The only time Siam was picky about the location of its pavilion was at the 1900 Paris exhibition, where Siam was originally placed among the colonies. Siam refused and was relocated (NA R.5 B 11/17). ${ }^{21}$ Otherwise, the organizers of the Siamese exhibits were often eager to send a village, people, and a dancing troupe to the fairs, although most of the time it was not possible because of limited budgets.

In most cases, Siam displayed crafts, arts, and natural products from all over the country. They were selected from the items that Bangkok ordered from provincial authorities particularly for World's Fairs. Products from private companies in Bangkok were also welcome. Somerimes the nobles were assigned to make special exhibits of arts and crafts (NA. R.5 B 11/17). On the other hand, Siam usually took the opportunity to show its technological progress in such areas as postal and telegraphic services, railways, or the first modern map made in Siam (Peleggi 1997, $174-75,181)$. It seems that they had to strike a balance as to how to display Siam as a siwilai country, between the modern, technologically developing nation, and the ancient kingdom with archaic and exotic culture.

Unfortunately, Siam's preoccupation with its position in the world and its selfperception of relative superiority was a delusion for domestic consumption. For the host and its public in the West the place of Siam was predetermined: namely, as one among the Others of Western civilization, although not the barbaric one. The local exotica were exactly what the hosts usually expected from Siam. As the organizers and local critics of many exhibitions noted, products from Siam showed the beauty of simplicity and elegance of the preindustrial age (Peleggi 1997, 169-73, 178-80). In other words, they served the arrogance and nostalgia of the industrialized society well. Siam collected numerous awards every time for its products. On the other hand, the organizers of the fair at St. Louis in 1904 were obviously disappointed at the exhibit

${ }^{18}$ The main archival sources for Siam in the World's Fairs are NA KT 54. See esp. 54/3 and 54/14 concerning the organizers; 54/17, 54/36, 54/58 about anticipated benefits; 54/2, $54 / 24,54 / 27,54 / 45$ and 54/61 about budget and cost savings. Most invitations to the smaller and specialized exhibitions were turned down. The only major one that Siam turned down due to financial reasons was the Imperial International Exhibition, Crystal Palace, England 1909 , see 54/59. Some files in the NA R.5 B also have documents on this matter.

${ }^{19}$ The only time the Siamese government was reluctant to participate due to ideological differences was the Paris 1889 centennial celebration of the 1789 French revolution, which a few monarchical regimes like England and Austria protested. Eventually Siam participated (see NA KT 54/2). At other fairs, colonial ideology was never a factor in consideration.

${ }^{20}$ See Rand McNally and Co. 1893, New Indexed Miniature Guide Map of the World's Columbian Exposition at Chicago; and NA KT 54/15, the official brochure of the Siamese Exhibit at the Columbian Exposition.

${ }^{21}$ Unfortunately, the planned Siamese exhibit arrived in Paris when the exhibition was almost over. 
that displayed technological progress in Siam because the exhibit did not show the "national characteristics" of Siam (Peleggi 1997, 186). Presumably, that is to say, Siam should have been an exotic, half-civilized country on the progressing course.

There was no evidence that Siam's participation, and the numerous awards the country received every time, had elevated its status in the global view. After all, there were usually hundreds of awards and prizes given out at each World's Fair, the list of which was usually published in the Fair's bulletin or in local newspapers. The recognition of Siam were buried in there. It seems, nevertheless, that the Siamese themselves were anxious, overly excited, or proud of those awards (NA KT 54/39; NA R.5 B 11/53). Chulalongkorn's trip to Europe was to serve Siamese anxiety and curiosity rather than to be a diplomatic measure to get recognition from the Europeans. The quest for siwilai by being part of the civilized world at the World's Fairs was similarly a Siamese endeavor for local affirmation and a desire to confirm Siam's position among the world's civilizations. Whether or not the world really recognized Siam at the World's Fairs in the way Siam wished, might not matter much. ${ }^{22}$

\section{Museums and Exhibitions in Siam}

In 1859 a private museum, not open to public, was established in the Grand Palace, primarily to house royal regalia and antiques (Cary 1994, 61-64). Collections of antiques and curios were a hobby among the rulers at the time (41-43). In 1874 King Chulalongkorn opened a new royal museum, Ho Mewsiam [the Museum Hall] (Jira 1974). Every year on the king's birthday, an exhibition was held here where the aristocrats flaunted their private collections (Prachumkotmai 9: 157-59; Cary 1994, 72-81). At the Bangkok centennial celebration in 1882, the first public "National Exhibition" was held to show the charoen of the country (Prachumkotmai 10: 39-42). Participants included mostly the same group of the elite plus some private companies, and individuals. Exhibits included craft works, Buddhist icons, agricultural products, exotic and strange items, and old books (NA N R.5 B/16, and NA R. 5 B 11/7). Many items were exchanged and traded, including those owned by the king and the queen (NA N R.5 B/37). There were a few more small exclusive exhibitions among this group of elite, which were not open to public or were opened only after the aristocratic participants had enjoyed their exclusive gathering for some time. ${ }^{23}$

As Cary observes, a museum in Siam became part of the effort to construct a new subject position and a mechanism for inventing Siam (1994, 17-18). Antiquarianism and private collections of curios among the elite were a new elitist vogue at the time, unmistakably a mark of siwilai among these people who were conscious of the departure from the old age and the advent of the "modern" time. The number and

${ }^{22}$ Similar phenomena of self-confirmation happen from time to time up to the present day; for example, the fever when Miss Thailand (who grew up in California and whose lingua franca is English) won the Miss Universe pageant in 1987, and when a Thai boxer won the first Olympic gold medal in 1996. In both cases, the whole country was consumed by euphoria and endless celebrations. Nothing else mattered for quite a while because both events took Thailand to the top of the world, as it was said. Without demeaning these accomplishments, one may wonder who else in the world other than the 60 million Thais recognized their feats.

${ }^{23} \mathrm{~A}$ famous one was the exhibition in 1887 on Sichang Island, off the eastern coast about a hundred miles from Bangkok, see NA. R.5 B 11/7. 
sizes of private collections were hard to determine. Judging from the inventories of the first "National Exhibition" above, it was a serious hobby. Museums and exhibitions in Siam had their origins in these aristocratic collectors. As the royal collections expanded and the hobby became more serious, the Museum Department was created in 1893 as part of the bureaucracy, first to take care of the royal collections and later to establish the national museum (Jira 1974, 27-28).

In 1896 Chamun Srisorarak, the Director of the Museum Department, went on a European tour to visit the leading museums in England, France, and Germany as part of the preparation for the establishment of the first national museum in Siam. He visited four museums in each country. Upon his return, he wrote a lengthy report with recommendations to his boss, the Minister of Education. In London, Srisorarak was most impressed by the Imperial Institute, not the British Museum, and recommended that the national museum in Siam should follow that model. ${ }^{24}$ Opened only a few years earlier in 1893, the Imperial Institute was the museum where the colonies of the British Empire organized their own exhibits of local natural products, crafts, and industries. ${ }^{25}$ Those colonies, however, had to take responsibility of the expenses themselves. As its name suggested, the Institute was a museum of the British Empire, organized by the colonizer, at the center of the empire, for the spectacle of the colonized, at the latter's expense!

Did Srisorarak realize that it was a museum of imperialism? Apparently he did. As a matter of fact, exactly because of the imperial character of the museum, he thought it was the best model for the national museum of Siam. The national museum, he suggested, should be the place for exhibits of natural products, agricultural products, and manufactured commodities from the provinces (monthon) in Siam, just as the Imperial Institute was for British colonies. Likewise, those provinces should take care of the expense of their own exhibits (NA R.5 B 11/10, esp. pp. 52-54). This museum of commerce, craft, and industry should be given the top priority to promote production and commerce. But he also recommended a museum of natural history of the provinces in Siam to be the second in priority. If financially feasible, a museum of foreign countries (Europe, America, and others) and ethnology to display the varieties of peoples and races within the kingdom should follow.

The recommendation was never realized because of budget shortages and the notso-compelling need for a national museum. Nonetheless, the proposal was quite revealing in many ways. First of all, had the proposal been realized, it would have been an "imperial" museum with Bangkok as the imperial center of those provinces. Bangkok was likened to London, making Siam a parallel, though a smaller one, to the British Empire. In this sense, the rulers in Bangkok were likened to the British court, a center of the global siwilai. This was not a naive pretension or ambitious delusion. On the one hand, the courts in Southeast Asia claimed a genealogy from the source of cosmic power, typically by making the monarch a reincarnation of gods and the court itself a microcosm of the cosmic center. The legacy of this tradition, apparently, was alive and well in Bangkok at that time. On the other hand, the British Empire, a colonizer who conquered other nations, was not entirely dissimilar to the

${ }^{24}$ See the full report and subsequent correspondence on the matter in NA. R.5 B 11/10, esp. p. 47 for his recommendation of the Imperial Institute.

${ }^{25}$ See Golant 1984 for the history of the Institute. It faced financial problems most of the time. When the British empire drastically declined after World War II, the institute was closed. The only trace of the old Imperial Institute is its name, surviving as the Imperial College, an engineering school. 
premodern polity of overlordship and empire that Siam was. For the Siamese elite, the traditional empire and modern colonialism were in certain ways compatible. As a result, the latter was comprehensible through the conception of the former with which they were familiar. This was how Bangkok was likened to London. So were people inside the court.

Secondly, the Siamese imperial museum plus the museum of natural history, the second one in priority, would have been established by the rulers at the center for the display of the space, people and products of the rural Siam, the space of chaobannok, of human and natural resources, or the rural economy under the management of Bangkok who knew, collected data, processed them, and put them in order for display.

The museum of foreign countries and ethnology, the third one in the recommendation, would have been Siam's view of the more and less civilized peoples in the world. A geography textbook for elementary schools in 1902 gives us a hint of how the section on the non-European worlds might have been had the project been realized. One of the chapters is a fictional account of Thai students going to a "farang" [Western] circus. First, a couple of "Africans" come out with a camel. Then a crowd of tiny black men with thick lips and big bellies comes out, wearing animal skins and holding spears. These "wild" (pa) Africans, the book says, look like monkeys. Next, a man on horseback comes out, looking for food in the bush. He is from Latin America. The next one wears a feather headdress, the American Indian, followed by an ugly, dirty, almost naked man, the Australian aboriginal. The last group, the Caribbean cannibals, are decorated with bones (Tharaphakphathi 1902, 102-13). This would have been a Thai version of the Midway at Chicago in 1893. The typical world barbarians in the Thai imagination at that time were the African "Nigro" (Negroes) (see Thammasakmontri 1977, 85). Although the fictional circus does not specify the position of Siam in the world, it certainly indicates that Siam, the gazer, was more siwilai than those barbarians.

Had all the proposed projects come true, "Siam," as represented by all the national museums, would have been an imperial country of economic potential with vast exploitable natural and human resources, and with the less-civilized people along the borders of the Siamese civilization. An historical museum was not important in this scheme, ranking last in the recommended priority. Up until the end of the nineteenth century, the royal nationalist narrative was not developed enough to represent the biography of the nation that captures the spirit of Siam's siwilai. As I will elaborate elsewhere, the traditional mode of stories of the rises and falls of individual kings and kingdoms due to their merit was then in transition. Royal antiques had yet to tell the stories of the patriots and nation-building kings and dynasties. ${ }^{26}$ The master plot of a national history had not emerged until the mid-1910s. For Srisorarak and his contemporaries, the royal past could not have represented the siwilai Siam as well as the museums of the city, rural areas, wilderness, and foreign countries.

The national museum project was not totally abandoned. In fact, the idea of the museum of commerce, crafts, and natural products was behind the expansion and development of the royal collection, which was later turned into a public institution. Despite some traces of the collections of curios and antiquities, the royal collections became a museum of commerce and crafts from provinces all over the country. A large

${ }^{26}$ Cary 1994 suggests that the monarchy was the underlying principle of the national museum despite all the changes over the years. I would argue that this was true only for the 1926 Museum of Bangkok and after. 
number of items were selected from the ones sent to Bangkok in preparation for many World's Fairs. But the exhibits were organized by categories of products, not by the provinces of origin. Besides, the government in Bangkok picked up the cost. In other words, it was a permanent exhibit of the best products in Siam, as though the Siamese exhibits at the World Fairs were being put on show domestically.

Meanwhile, as the historical discourse of siwilai and the new nationalistic master narrative of Thai history was being developed, another transition of the museum was under way, beginning in the mid-1910s. When the Museum of Bangkok was formally opened in 1926 (later to become the National Museum in 1935), it was primarily a historical museum, although legacies of the previous collections remained.

By then the geographical discourse of siwilai remained side by side with the historical one. In 1926, a grand national exhibition of Siam was organized. Unfortunately, the king at the time, Vajiravudh, died shortly before the scheduled opening and the whole event was canceled. According to the plan, it would have been a huge exhibition, combining all four kinds of museum exhibits proposed by Srisorarak thirty years earlier. Commerce and commodities from all over the country remained the main theme of the exhibits (NA ST 19/219/6). A section was originally planned to display the various races in Siam. Obviously in imitation of World's Fairs, the idea was to house several tribal peoples at the exhibition for the entire event. The Thai (city) public would have a chance to walk around the housing section, observing the strange Others, not unlike the spectators did at the World's Fairs. But the idea was scrapped even before the exhibition was canceled due to lack of funding. A substitute plan, which was to have only pictures of those peoples, their housing, and living culture, died with the whole event (NA KT 54/102). The major difference from Srisorarak's ideas was the prominence of the history of Siam in the planned exhibition. In fact, the official volume of the exhibition (Thiraluk sayamrat phiphittbaphan n.d.) was primarily the official history of Siam, which by then was crystallized into the linear royal nationalist history, and became another discourse of the siwilai Siam which did not imply or rely on the comparative geographical scheme.

\section{The Geography of Siwilai}

Conspicuously absent from this article are discussions of Siam's neighbors and of the Chinese in Siam. Although occasionally Europe was contrasted with Siam's neighbors (Burma and Vietnam in particular) - the backward, miserable places that fell to colonialism (Thianwan in Chai-anan and Kattiya 1989, 115, 119, 120-23), I would argue that they serve as the otherness or the contrast with Siam in terms other than the less or un-siwilai ones. For example, Burma was generally seen as the wicked and heretical, the Evil One compared to Siam-the-true-Buddhist. The Chinese were the resident aliens from a great civilization, to whom respect or prejudice was due but was complicated by their classes. Moreover, the discourses on the neighbors are mediated primarily by history and myths, and not by spatial practices. The Chinese otherness is fundamentally not a spatialized category. In any case, they are major otherness of Siam that deserve separate projects.

This article has argued that the notion of siwilai, no matter how essentialized it was, could be conceptualized only by comparative geographical categories that implied the varying degrees of advancement. This conceptualization was crystal clear in a 
famous play, Pbonlamuangdi [Good citizen], written in 1916. When the shorter version became a text in elementary schools, the title was changed to "Nai thuan pen nai muang" [From Mr. Jungle to Mr. City]. In this story, a boy named Thuan, a synonym of $p a$, came to the city after his father had died in the dangerous jungle, to live with his uncle who was a bureaucrat. He was trained and taught various subjects, including good manners such as gentility. The boy, who was initially seen by the city dwellers as "ancient boy" [dek boran) changed his identity completely from head to toe, inside and our, then changed his name from Thuan to Muang (town or city). The boy grew up to become a policeman, loyally serving the nation, the religion, and the monarchy (Wiphatwithayasat 1964). The boy represents all Siamese subjects whom the elite wanted to change completely to make them, and thereby the country, siwilai.

The categories in this geography of civilization did not follow the political, sociological, or economic divisions, and cut across the global, regional, national, and local levels. Siam was not an undifferentiated geographical unit. The elite and the city were located above or ahead of the rural hinterland and the untamed margins, but they were behind and below Europe. The rapidly changing world mesmerized the Siamese elite. They tried to understand and locate their position in the new world order. After all, indignity was the worst and most serious damage to the absolute monarch. The quest for siwilai was a genuine desire to avoid the disgrace of inferiority for being less civilized. The Siamese elite in the late nineteenth century sought to obtain and appropriate a new source of superiority, for they did not want to be seen as inferior, and did not want to be left behind or below. To build up confidence in one's own siwilai, the evaluation scheme must be a self-fulfilling one in which the Siamese elite could assure or prove to themselves of their siwilai, no matter how others might think. The quest for siwilai was outward looking, yet fundamentally a selfconfirmation.

By the end of the twentieth century in Thailand and elsewhere, the connotations of forest in relation to the city in terms of siwilai has changed drastically. While the latter has increasingly been regarded as an evidence of the decadence of modernity, forest has been seen as the fountain of life and the future of civilization. During the same time, nonetheless, the New Rich in Thailand was scrambling to get to the forefront of globalization [lokapbiwat-in Thai], or the post-Cold War world order. Like their royal predecessors a century earlier, the spatial concept and strategy were subtly at work, both within and without the country, in order to get to the desirable position in the world.

\section{List of References}

Unpublished Documents from the National Archive (NA), Bangkok

NA KT $=$ Documents of the Ministry of Foreign Affairs (Kan Tangpratbet)

NA $\mathrm{N}=$ Documents of the City Administration (Nakbonban)

NA R.5 = Documents from the fifth reign (King Chulalongkor)

NA R.5 B = Miscellaneous (Bettalet) documents from the fifth reign

NA ST $=$ Documents of the Ministry of Education (Suksatbikan)

\section{Other Printed Materials}

Battye, Noel. 1974. "The Military, Government, and Society in Siam, 18681910." Ph.D. diss., Cornell University. 
Benedict, Burton. 1983. The Antbropology of World's Fairs. Berkeley: Lowie Museum of Anthropology and Scholar Press.

__ 1994. "Rituals of Representation: Ethnic Stereotypes and Colonized Peoples at World's Fairs." In Fair Representation: World's Fairs and the Modern World, edited by Robert Rydell and Nancy Gwinn. Amsterdam: VU University Press.

Bidhayalongkorn, Prince. 1970. "Phawa yangrai no thi riakwa siwilai" [What is the condition called civilized?]. In Prachum pathakatba kbong kromamun phitthayalongkon [Collected lectures by Prince Bhidayalongkorn]. Bangkok: Ruamsan.

Bowring, Sir John. [1857] 1969. The Kingdom and People of Siam. 2 vols. Reprint, Kuala Lumpur: Oxford University Press.

BRADley, William. 1981. Siam Then: The Foreign Colony in Bangkok Before and After Anna. Pasadena, Calif.: William Carey Library.

Cary, Caverlee. 1994. "Triple Gems and Double Meanings: Contested Spaces in the National Museum of Bangkok." Ph.D. diss., Cornell University.

Chai-Anan Samudavanija, and Kattiya KanNasutr, comp. 1989. Ekkasan kanmuang kanpokkbrong thai 2411-2475 [Documents on Thai politics and administration 1868-1932]. 2nd printing. Bangkok: Social Science Association of Thailand.

ChalONG SUNTARAW ANIT. 1997. "Kanmuang buanglang kansadetpraphat yurop" [Politics of the trip to Europe]. Unpublished paper presented at the conference on the centennial of the first trip to Europe by King Chulalongkorn organized by the Siam Society, Bangkok.

Chandran Jeshurun. 1970. "The Anglo-French Declaration of January 1896 and the Independence of Siam." Journal of the Siam Society 28 (pt. 2):105-26.

Charnvit KASETSIRI. 1996. "Siam/Civilization, Thailand/Globalization." Unpublished paper presented at the International Association of Historians of Asia (IAHA). Bangkok.

Chulalongkorn, KING. 1962 and 1983. Chotmaibet sadet praphat Yurop R.S. 116 [Records on the trip to Europe in 1897]. 2 vols. (2nd vol. reprint), Bangkok: Khurusapha.

Cushman, Jennifer. 1993. Fields from the Sea: Chinese Junk Trade with Siam during the Late Eighteenth and Early Nineteenth Centuries. Ithaca, N.Y.: Southeast Asia Program, Cornell University.

Damrong Rajanuphap, Prince. 1961. Athibai ruang thieo [Explaining about tours]. Bangkok: Khurusapha.

. [1942] 1966. Nithan borankbadi [Tales of the past]. 13th printing. Bangkok: Bannakhan.

Delcore, Henry. 2000. "Practicing Development: Environment, Agriculture, and Memory in Northern Thailand." Ph.D. diss., University of Wisconsin-Madison.

Elias, Norbert. 1978. The Civilizing Process. Translated by Edmund Jephcort. New York: Urizen Books.

Fabian, JoHAnNes. 1983. Time and the Other: How Antbropology Makes Its Object. New York: Columbia University Press.

GOLANT, WILlIAM. 1984. Image of Empire: The Early History of the Imperial Institute 1881-1925. Exeter: University of Exeter.

Fukuzawa, YuKICHI. 1973. An Outline of a Theory of Civilization. Translated by David Dilworth and Cameron Hurst. Tokyo: Sophia University.

JIRA JONGKOL. 1974. Kitchakan phiphittbaphan sathan [Museums]. Bangkok: Fine Arts Department. 
Kamala Tiyavanich. 1997. Forest Recollections: Wandering Monks in Twentieth Century Thailand. Honolulu: University of Hawaii Press.

K. S. R. Kula . 1995. Ayatiwat [Progress]. Reprint. Bangkok: Thai-Japanese Friendship Association.

Latthi thamniam tangtang [Various customs]. 1972. 2 vols. Bangkok: Khlangwitthaya. LithaI, PHYA. 1983. Traiphum phraruang [Three worlds according to King Ruang]. Bangkok: Fine Arts Department.

Mahintharasakthamrong, Chaophraya. 1988. Chan phrasi. Cremation volume for Colonel Luang Amnat naronghan (Phaithun Phenkul).

Mananya Thanaphum. 1996. K. S. R. Kulap [Mr. K. S. R. Kulap]. Bangkok: Chulalongkorn University Press.

Manas Chitakasem. 1972. "The Emergence and Development of Nirat Genre in Thai Poetry." Journal of the Siam Society 60 (pt. 2):135-48.

Mitchell, Timothy. 1988. Colonising Egypt. Cambridge: Cambridge University Press.

MONGKUT, KING. 1973. Prachum phraratchaniphon ratchakan thi 4 [Collected writings of King Mongkut]. Cremation volume for Phra Thammadilok (Thongkham Chanthupamo).

Peleggi, Maurizio. 1997. “The Making of the Siamese Monarchy's Modern Public Image." Ph.D. thesis, Australian National University.

Pbraratchaputcha nai chan krung rattanakosin [The royal conversations regarding religious matters in Bangkok period]. 1970. vol. 2. Bangkok: Khurusapha.

PrachaKhadikit, KHUN. 1885. "Waduai praphet khonpa ru kha fainua" [On various jungle peoples or slaves in the north]. Wachirayanwiset 1(9):164-66.

Prachumkotmai prachamsok [Collected annual law codes]. Multiple volumes.

PRATT, MARY LOUISE. 1992. Imperial Eyes: Travel Writing and Transculturation. London and New York: Routledge.

PRAYUT SitThiphan. 1971. Tam roibat phraphuttbacbaoluang [Following the footstep of King Chulalongkorn]. Bangkok: Sayam.

Reynolds, Craig. 1976. "Buddhist Cosmology in Thai History with Special Reference to Nineteenth Century Culture Change." Journal of Asian Studies 35:203-20.

Rydell, RoBert. 1984. All the World's a Fair. Chicago: University of Chicago Press. . 1993. World of Fairs: The Century of Progress Expositions. Chicago: University of Chicago Press.

SRISAHATHEP (seng), Phraya. 1972. Chotmaibet sadetprapbat yurop ro.so.116 [Records of the royal visit to Europe in 1897]. 6 vols. Bangkok: Khurusapha.

StotT, Philip. 1991. "Muang and Pa: Elite Views of Nature in a Changing Thailand." In Thai Constructions of Knowledge, edited by Andrew Turton and Manas Chitakasem. London: School of Oriental and African Studies.

Surasakmontri, ChaOphraya. 1972. "Waduai chaopa chat tangtang" [On various jungle races]. In Lattbi thamniam tangtang [Various customs]. Vol. 1. 4th printing. Bangkok: Khlangwithaya. Originally in Wachirayanwiset 5 (1889): 518, 534, 548, 558, 567 .

Tambiah, S. J. 1976. World Conqueror and World Renouncer. New York: Cambridge University Press.

TAYLOR, LISA MCQUill. 1991. "Articles of Peculiar Excellence: the Siam Exhibit at the US Centennial Exposition (Philadelphia), 1876." Journal of the Siam Society 79 (pt. 2): 13-23. 
Thammasakmontri, Chaophraya. 1977. Thammacbariya [Good behaviors]. Vol. 4. Bangkok: Bannakit.

Thampricha (KAEW), Phra. 1992. Traipbum lokwinitchayakatha [Three worlds treatise]. Vol. 1. Bangkok: Fine Arts Department.

TharaphakPhathi, KHUN. 1902. Phumisat lem 1 [Geography, vol. 1]. Bangkok: Aksonnit.

- 1904. Nangsu an phumisat Lem 2 [Geography textbook, vol. 2]. Bangkok: Aksonnit.

ThaWEeSilp SubW ATthanA. 1988. " 'Lao' nai thatsana khong phupokkhrongthat samai rattanakosin" ['Lao' in the perceptions of the Thai rulers in the Bangkok period]. Chotmaikhao sangkhomsat [Social science bulletin] 11; 1 (AugOct):105-21.

ThIPHAKORAwONG, CHAOPHRAYA. 1961. Phraratchaphongsawadan krung rattanakosin ratchakantbi 4 [The royal chronicle of Bangkok, the fourth reign]. Vol. 1. Bangkok: Khurusapha.

- 1971. Nangsu sadaeng kitchanukit [A book on various matters]. Bangkok: Khurusapha.

Thiraluk sayamrat phiphitthaphan suan lumphini phraphutthasakkarat 2468 [The Souvenir of the Siamese Kingdom Exhibition at Lumbini Park B.E. 2468]. Reprint. n.d. n.p.

ThongChai Winichakul. 1994. Siam Mapped: A History of the Geo-body of a Nation. Honolulu: University of Hawaii Press.

—. 2000. "The Others Within: Travels and Ethno-spatial Differentiation of Siamese Subjects, 1885-1910." In Civility and savagery: social identity in Tai states, edited by Andrew Turton. London: Curzon.

Vella, Walter. 1957. Siam under Rama III (1824-1851). New York: Association for Asian Studies.

Williams, Raymond. 1983. Keywords. New York: Oxford University Press.

WiPhatwitThayasat, LUANG. 1964. "Botlakhon phut ruang phonlamuangdi" [Play-script titled "Good citizen"]. Botlakbon phut ruang khaochaiphit, waenta khong khunphi, phonlamuangdi [Play-scripts titled "Misunderstanding," "My husband's glasses," and "Good Citizen"]. Bangkok: Khurusapha, pp. 263-306.

Wolters. O. W. 1994. "Southeast Asia as Southeast Asian Field of Study." Indonesia 58:1-17.

WyatT, David. 1983. Thailand: A Short History. New Haven, Conn.: Yale University Press. 